\title{
ROLE OF BANKS IN SUSTAINABLE AND DIGITAL TRANSITION
}

\section{Bożena Ryszawska}

Wrocław University of Economics, Wrocław, Poland

e-mail: bozena.ryszawska@ue.wroc.pl

(C) 2018 Bożena Ryszawska

This is an open access article distributed under the Creative Commons Attribution-NonCommercial-NoDerivs license (http://creativecommons.org/licenses/by-nc-nd/3.0/)

DOI: 10.15611/fins.2018.1.05

JEL Classification: Q01, Q54, Q56, G23

\begin{abstract}
The purpose of this study is to identify how the sustainability and digital transition influence banks. The main thesis can be expressed as follows: sustainability transition and digital transition are changing the role and function of banks, especially the products and services offered by banks. Banks are one of main actors of a broader, multi-level governance designed to support the transition to smart, efficient and low carbon economy. The framework's structure is based upon the multi-level perspective on socio-technical transitions created by F.W. Geels. The first section of this paper presents the most popular approaches to the problem at hand, as reported in professional literature. Section two presents characteristics of the various actors involved in the anticipated transformation of the economy. The third section discusses the changing roles and frameworks of banks associated with the notion of the broader concept of sustainability and digitalization.
\end{abstract}

Keywords: sustainable transition, digital transition, banks.

\section{Introduction}

Sustainability transition is currently the most important multi-level transformation of the economic and socio-technological system intended to increase its environmental sustainability and social fairness. The motor of this approach is sustainable growth which will help to decouple economic growth from the use of resources, support the shift towards a low carbon economy, increase the use of renewable energy sources, modernize our transport sector and promote energy efficiency. We can say that the present problems, both environmental (such as climatic changes, the loss of bio-diversity and depletion of natural resources) and social (mostly associated with steep inequalities in income distribution), present an enormous challenge to economic development. Those problems can only be faced by means of deep structural changes to the adopted production and consumption patterns. Changes of this scale can only be effected through concerted effort of various economic actors: companies, industry sectors, decision-makers, political powers, consumer groups, active civil societies, 
engineers, and scientists. In effect, the postulated transition should be interpreted as a complex and prolonged process involving a multitude of areas and actors [Geels 2011].

The purpose of this study is to identify how the sustainability and digital transition influence banks. The main thesis can be expressed as follows: sustainability transition and digital transition are changing the role and function of banks, especially the products and services offered by banks. Banks are one of main actors of a broader, multi-level governance designed to support the transition to smart, efficient and low carbon economy. The framework's structure is based upon the multi-level perspective on socio-technical transitions created by F.W. Geels. The first section of this paper presents the most popular approaches to the problem at hand, as reported in professional literature. Section two presents characteristics of the various actors involved in the anticipated transformation of the economy. The third section discusses the changing roles and frameworks of banks associated with the notion of the broader concept of sustainability and digitalization.

\section{Multilevel perspective as an analytical tool of sustainability and digital transition}

The article uses the multilevel perspective created by F.W. Geels effective in the analysis of the sustainability and digital transition. It is based on the assumption that the transformation is not a linear process but a joint effect of occurrences observed on three distinct levels: in niches - as areas associated with radical innovations, new technologies, digitalization of services, new skills and values in young generation; in the dominant economic, technological and social system (the existing patterns of production, consumption, management, and legislation - the socio-technical regime); in the external economic, social and technological environment (demographic trends, political ideologies, financial crises, social values, and macroeconomic principles the socio-technical landscape). The sustainability and digital transition is an end result of all interactions that occur between processes on each of the above levels. In this view, niches are the environment involved in the initiation of changes with potential to accelerate changes in the dominant system, while processes observed in the external surrounding exert pressure upon the system. Destabilisation of the dominant system, in turn, forms windows of opportunity for further innovations generated at niche level [Geels 2013]. The second part of the methodological approach is actor analysis concept. There are various groups of actors, which play important role in transition process: state authorities (governments), decision makers, and local self-governmental bodies; enterprises, banks; consumers and non-governmental organisations (civil society) [Loorbach, Lijnis Huffenreuter 2013]. By using specific instruments and taking certain actions they influence the process. 


\section{The sustainability and digital transition concept}

The sustainability transition process has reached an unprecedented scale, with active involvement of a broad spectrum of stakeholders (business actors, the government, the consumers). One of its manifestations is the sizeable contribution on the part of international organisations and individual countries - their activities, undertaken in response to global crisis, come as part of much broader strategies of development and new policies, strongly rooted in the concepts of sustainable growth, green economy and clean production as the most effective remedies with potential to revitalise and sanitise the economy. The influx of crisis symptoms and problems in the economic, environmental, social and political spheres has gained pace with the outburst of the latest global financial crisis. The most profound effect was the acceleration of fundamental systemic changes which - by their strongly voiced opposition to the existing system resulting in rapid generation of aggravated imbalance - naturally tends towards the sustainability transition [Loorbach, Lijnis Huffenreuter 2013].

The growing trend can also be found with respect to general awareness of the fact that some of the recent changes observed throughout the world should be perceived as systemic risks or hazards, i.e. factors that are no longer contained within the narrow framework of individual problems, but pose a serious threat to the operation or the very existence of the entire system. Systemic risks may be triggered by certain events or evolve over time, and their effects are typically grave, with potential to reach catastrophic dimensions. Some of the most pronounced risks are produced as consequence of protracted, long-drawn processes and only come into light when certain threshold values are breached. Consequently, it may take decades before the full extent of their damage can be recognized or anticipated. Until then, their potential impact upon the economy and the society tends to be downplayed or underestimated. Following are some of the examples of the present systemic risks:

- climate change and the loss of biodiversity - these are interconnected, complex and typically of global scale;

- imbalanced and unsustainable use of resources across various economic and social systems - these have the effect of limiting the ecosystem's ability to provide its services (such as waste absorption or the supply of production resources, water, breathable air, etc.);

- environmental challenges - of more complex character, strongly correlated to other social problems, and resulting in an influx of uncertainty and risk,

- digital revolution -new technologies, innovation which change the way how we consume and produce, how we communicate and spend time.

In this sense, transition is a term used to describe conversion (evolution) from the existing model of economy towards one based on increased social and environmental responsibility. The new model should emphasize such elements as: green economy, low emission, resource efficiency, clean technologies, responsible consumption, 
social justice and equality (both inter- and intra-generational). Transition to smart, efficient, low carbon economy (called sustainability transition) in conventional reception is associated with the process of multi-level transformation of the economic and socio-technological system intended to increase its environmental sustainability and social fairness.

The significant element of transition is digitalisation and digital transformation. Technological innovations are important driver of changes in societies, in production, consumptions and communications between people. Digitalization change business model also in financial system specially in banking sector. Digitalisation is described as a "global megatrend that is fundamentally changing existing value chains across industries and public sectors" [Khan 2016]. Examples of digital transformation can be seen in the media, banking, telecom and insurance industries as pioneering sectors that are in the middle of large-scale digital transformation. Today digitalization works as the catalyst, enabler and engine of societal development.

It may be observed that some of the processes which, up till recently, were only registered at the niche segments and peripheral areas of the economy, are gradually seeping to the mainstream, turning the brown economy of overabundance into a green economy of moderation and restraint. Some of the manifestations of this process include such phenomena as: the growing share of energy from renewable sources in total energy production, waste recycling, reduced greenhouse gas emission, of modern products and technologies with improved energy efficiency, digitalization which shifts consumption of products to services, sustainable transportation, sustainable supply chains, sustainable consumption, collaborative consumption, corporate social and environmental responsibility, corporate sustainability.

The process of transformation that can be witnessed at present is - in its essence - a manifestation of structural changes. Research results and statistical data confirm the growing impact of green economy upon the GDP and employment rates, thus elevating its significance as a source of competitive advantage, a mark of sectoral development and a potent attractor for public and private investors. This is a new and very distinct trend. Observation and interpretation of structural changes associated with such concepts as green economy, green growth, green entrepreneurship and green employment are an important and current topic for in-depth studies. This is particularly evident in those areas where science meets politics. On the one hand, politicians voice their demand for broad and accurate analyses of the complex system of economy-society-environment. On the other hand, the scientific community requires political support and political experiences to facilitate the implementation of practical solutions and remedies.

As aptly observed by M. McIntosh, we are witnesses to several concurrent transformation processes at present: from high-emission to low-emission economy; from deep imbalance in income distribution to egalitarianism; from glaring practice of neglect for basic human rights towards communities formed on the sound fundaments of social justice [McIntosh 2013]. On the other hand, I. Røpke suggests 
that the present changes are concentrated in two distinct areas, namely production and consumption, particularly the sociotechnical system of energy production and distribution, transportation system, and methods of food production [Røpke 2013].

The intellectual insight into such complex interplay of diverse aspects of the present changes is severely limited by the strong compartmentalization (if not fragmentation) of modern science and the associated reluctance on the part of many researchers to bear the intellectual risk of an interdisciplinary approach to the problems at hand. The more so that the phenomena observed at present are exceedingly complex and often burdened with unpredictability, thus adding to the complexity of their interpretation and under-standing. It must be noted that the key notions evoked in the context of the present transition trend are: learning, adaptation, and transformation. Since the problems at hand are complex and not readily associated with distinct cause-effect relationships, the suggested approach is to keep on learning from one's actions, to observe, to adapt to changes as they come, and to accept the process of continuous transition. M. McIntosh in The Necessary Transition... emphasises his strong conviction that the transition is a necessary stage, that it is already under way, and that it should be regarded as a positive trend, since it allows us to better address the present challenges faced by the world [McIntosh 2013].

Transformation towards a new model of economy may be approached not only through proper coordination and cooperation between governmental institutions and international organisations, but also through cooperation between business entities and their stakeholders. The sustainability transition as such may be presented in a graphical form as a multi-level structure [Geels 2011]. The above approach (Figure 1) is based on the assumption that the transformation is not a linear process but a joint effect of occurrences observed on three distinct levels:

- in niches - as areas associated with radical innovations;

- in the dominant economic, technological and social system (the existing patterns of production, consumption, management, and legislation - the socio-technical regime);

- in the external economic, social and technological environment (demographic trends, political ideologies, social values of generations $\mathrm{Z}$ and $\mathrm{Y}$ living on line $24 \mathrm{~h}$ - the socio-technical landscape).

The sustainability transition is an end result of all interactions that occur between processes on each of the above levels. In this view, niches are the environment involved in the initiation of changes with potential to accelerate changes in the dominant system, while processes observed in the external surrounding exert pressure upon the system. Destabilization of the dominant system, in turn, forms windows of opportunity for further innovations generated at niche level [Geels 2011].

The sustainability transition imposes a number of changes: limitation of economic scale - both for production and consumption; departure from the imperative (or dogma) of economic growth; limitation of social inequalities (both in national and global perspective); reduction of macroeconomic instabilities and imbalances; 


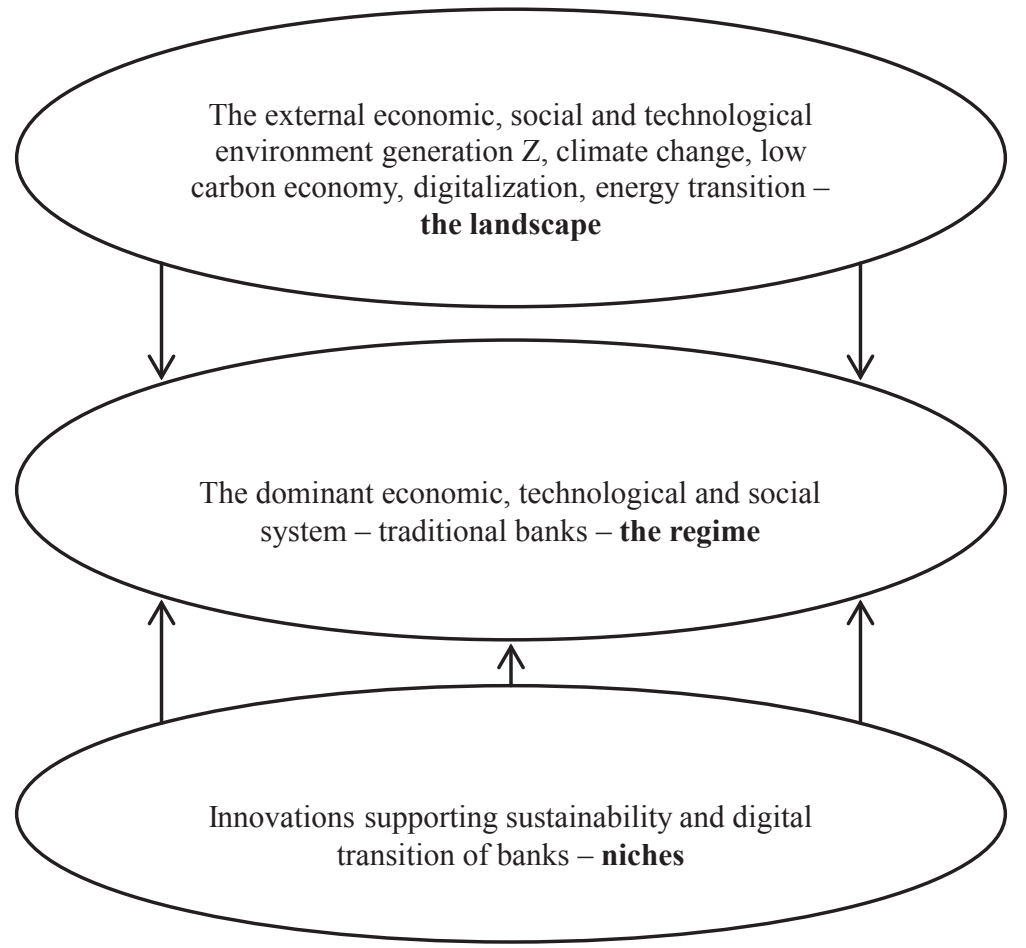

Figure 1. Sustainability transition

Source: [Geels 2011].

adaptation of public institutions to the requirements of new economy (free from the constraints of strong reliance on fossil fuels), depletion of natural resources, and degradation of the natural environment. As such, it represents a change towards local economies, with less complexity, and with potential to stimulate social involvement in small-scale, local, grassroots projects [Røpke 2013].

\section{The banks as actors of sustainability transition}

The transition we discussed in this paper is a conglomerate of processes occurring in parallel in the spheres of economy, technology (digitalization), politics, and civil societies. The above processes stimulate the involvement of many actors - those can be segregated into the following groups:

- state authorities (governments), decision makers, and local self-governmental bodies;

- enterprises, banks, financial institutions;

- consumers and non-governmental organisations (civil society). 
Each of the above groups plays their specific role in the transition processes, using their specific sets of resources and other instruments, as adequate for the task at hand [Røpke 2013].

It seems that the first of the above groups of actors plays the most decisive role in the processes at hand, at least in the initiation of changes. After all, the political decision makers, in cooperation with scientific communities, were the ones to initiate the process of diagnosing the present crisis situation. Governments and international organisations are the obvious proponents of any strategies, policies and remedial measures designed to address the challenges associated with the systemic crises.

The banks and enterprise sector, in turn, is involved in the realisation of the concept of social and environmental responsibility, designed to reduce the negative impact of the sector upon the natural environment and the society at large. These actors are involved in the introduction of new, clean technologies and Eco-Management and Audit Schemes (EMAS) in support of environmental innovations. Recent years have brought an increased interest in the concept of Corporate Sustainability to broaden the scope of the existing Corporate Social Responsibility and to better address the challenges of the sustainability transition, as discussed herein.

The last group of actors - consumers and non-governmental organisations - is involved in the task of changing the existing cognitive and behavioural patterns through education, information campaigns, and grassroots pressure upon decision makers. The growing awareness of the consumer base will result in increased demand for environmental goods and services, to the effect of stimulating greater involvement of business entities in the task of changing the existing production and supply of these products.

Authors of Positive Finance write: "Transforming the economic model is extremely costly. We have to re-envision the allocation of capital in order to support social and technological innovations, to design and build sustainable infrastructure, and to finance the energy transition. Reinvented, finance could become a powerful lever for setting these transformations in motion" [Guez, Zaouati 2015].

\section{How banks adjust to sustainability and digital transition}

Sustainability and digital transition is a multilevel process which means reaching goals of sustainable development, transforming economy towards green, low carbon, resource efficient taking into consideration transformation created by innovation and new technologies in societies, in production and consumption (Table 1).

New trends on the market, new business models, changing customer expectations and fragmentation of traditional services are all contributing to put traditional banks under pressure. Banking is becoming more democratised by technology and new services are changing the way we think about banking, our money and the application and capability of technology. Customers want a more holistic and engaging experience that can span channels and be supported in by them all [Merriman]. 
Table 1. Banks in sustainable and digital transition

\begin{tabular}{|c|c|}
\hline Sustainability transition & Digitalization transition \\
\hline $\begin{array}{l}\text { Social and environmental responsibility, } \\
\text { designed to reduce the negative impact of the } \\
\text { sector upon the natural environment and the } \\
\text { society at large, } \\
\text { Financing renewable energy, low carbon } \\
\text { economy, financing local green growth, green } \\
\text { public procurement, domestic low carbon } \\
\text { economy and climate finance }\end{array}$ & $\begin{array}{l}\text { Innovation drives success, } \\
\text { New customers - generations } \mathrm{Y} \text { and } \mathrm{Z} \\
\text { Personalization } \\
\\
\text { Democratization } \\
\text { Decentralization } \\
\text { Access } 24 / 7 \\
\text { New services } \\
\text { Banking not banks }\end{array}$ \\
\hline
\end{tabular}

Source: authors own elaboration.

Banks worldwide recognize the importance of providing a digital banking experience that is comparable with what their customer have come to expect from their digital interactions with other industry verticals, notably retail. Banks have to move away from their traditional focus on simply delivering automated transaction toward offering comprehensive digital customer experience: identity, access, location, data, intelligence [Digital Innovation... 2016, pp. 5, 6].

The majority of established banks already have the platforms to deliver new services - the challenge is in the exploitation. The ability to join the product centric thinking into a more customer centric and focused set of offerings will challenge traditional operating models. It requires the skills of an IT department that takes a holistic approach to change.

Recently many new sustainable initiatives emerged in banking and finance: Green Climate Found and national climate founds. established as the investment vehicle for climate finance (USD 100 billion per year by 2020, from a variety of sources) [Green Climate Fund 2015]; National public finance - fiscal policy for green economy, budget's expenditures supporting green sectors, taxes, decreasing subsidies for harmful production, green public procurement, investment in green public infrastructure, researches and development expenditures for ecoinnovations and green technology. The consequences of sustainability transition in banking and finance is a huge challenge for science to address all important issues, to help the audience to understand new process, to design survey, to create new models and tools to explain structure and function of sustainable finance system. The role of science is not only describing and analysing new role of public finance in transformation but also prediction of future trends which has meaning for business, banks, governments, financial markets, university education and society. 


\section{Conclusions}

Based upon the analytical framework, major challenges of multilevel transition has been recognized. The sustainability and digital transition process has reached an unprecedented scale (planetary, global, local) and involved many actors (international organizations, EU, national and local governments, banks, enterprises, civil society, universities). We got aware that active role of banks is necessary.

There is a common interest of governments, banks and business to finance sustainability transition. Specially the state policy and actions are important, without them the power of private sector is useless. The state role as rule-setter and enforcer is crucial for successful implementation of sustainable economy. The economy-asusual cannot get us to sustainability or secure economic and social prosperity. Banks support sustainability transition. Recently new financial initiatives occurred: like climate finance, green finance, carbon finance. It is a structural change in financial system on many levels: international, public, corporate and household finance. The old role of banks destabilizes. Banks are slowly responding to new demand in sustainable economy to align with it. It may be observed that traditional banks as an institution are changing towards banking as a service adjusted to digital innovation, decentralized and sustainable production and consumption. Some of the manifestations of this process include banks as an active player in financing production of energy from renewable sources, waste recycling, reduction of greenhouse gas emission, modern products and technologies with improved energy efficiency, sustainable transportation, sustainable supply chains, sustainable consumption.

\section{References}

Digital Innovation in Bank, Intel, Red Hat, 2016, https://www.sifma.org/resources/general/digital-innovation-in-banks-it-infrastructure-modernization-accelerates-progress (access 10.03.2017).

Geels F.W., 2011, The multi-level perspective on sustainability transitions: Responses to seven criticisms, Environmental Innovation and Societal Transitions, vol. 1, no. 1, pp. 24-40.

Geels F.W., 2013, The impact of the financial-economic crisis on sustainability transitions: Financial investment, governance and public discourse, Environmental Innovation and Societal Transition, no. 6, pp. 67-95.

Green Climate Fund, 2015, Investment Opportunities for the Green Climate Fund, Elements Issue 02, November.

Guez H., Zaouati P., 2015, Positive Finance. A Toolkit for Responsible Transformation, Greenleaf Publishing, London.

Khan S., 2016, Leadership in the digital age - A study on the effects of digitalisation on top management leadership, Stockholm Business School Master Thesis $30 \mathrm{HP}$, Stockholm, https://su.diva-portal.org/smash/get/diva2:971518/FULLTEXT02.pdf (access 10.03.2017).

Loorbach D.A., Lijnis Huffenreuter R., 2013, Exploring the economic crisis from a transition management perspective, Environmental Innovation and Societal Transitions, vol. 6, no. 1, pp. 35-46. 
McIntosh M., 2013, The Necessary Transition. The Journey towards the Sustainable Enterprise Economy, Greenleaf Publishing, London.

Merriman N., From banks to banking - a new era of customer focused innovation in financial services, http://www.ukfintech.com/future-of-fintech/from-banks-to-banking-a-new-era-of-customer-focused-innovation-in-financial-services (access 10.03.2017).

Røpke I., 2013, Sustainability transitions in the perspective of ecological macroeconomics, The $10^{\text {th }}$ Biennial Conference of the European Society for 6. Ecological Economics, European Society for Ecological Economics, Lille.

\section{ROLA BANKÓW W ZIELONEJ I CYFROWEJ TRANSFORMACJI}

Streszczenie: Celem tego badania jest określenie, jak zrównoważony rozwój i cyfryzacja wpływają na banki. Główne tezy można wyrazić następująco: zielona i cyfrowa transformacja zmienia rolę i funkcję banków oraz ma wpływ na produkty i usługi oferowane przez banki. Banki są jednym z głównych aktorów wielopoziomowego procesu trasformacji w stronę gospodarki niskoemisyjnej. W artykule wykorzystano podejście wielopoziomowe stworzone przez F. Geelsa. Pierwsza część artykułu jest przeglądem literatury dotyczącej zielonej i cyfrowej transformacji. W części drugiej przedstawiono poszczególne podmioty zaangażowane w proces transformacji gospodarki. W końcowej części omawiana jest zmiana roli i struktury banków w warunkach cyfryzacji i zielonej transformacji.

Slowa kluczowe: zielona transformacja, cyfrowa transformacja w bankowości. 